"The Prince and the Discourse: On Commenting and Advising on International Law", in Nordic Cosmopolitanism: Essays for Martti Koskenniemi 33-47 (Jarna Petman \& Jan Klabbers eds, Leiden: Brill, 2003).

This is, to the best of my knowledge, the submitted version of the text.

\title{
The Prince and the Discourse - commenting and advising on international law
}

Pål Wrange ${ }^{1}$

1. Every act of reading or writing is site-specific. Being in Florence at the time of writing, Niccolò Machiavelli comes to mind. ${ }^{2}$ Not that there are any obvious links between him and Martti Koskenniemi or between Machiavelli and international law. ${ }^{3}$ But, every text has to start from somewhere. And often the choice of an odd or slightly uncomfortable cite may generate new ideas. ${ }^{4}$

2. Quentin Skinner's standard introduction to Niccolo Machiavelli (NM), has the following table of contents: The Diplomat, The Adviser to Princes, The Philosopher of Liberty, The Historian of Florence. ${ }^{5}$ Diplomat, adviser, philosopher and historian

\footnotetext{
${ }^{1}$ Senior Legal Adviser at the Swedish Ministry for Foreign Affairs, currently at the European University Institute on a leave of absence, generously paid by my employer. The views presented here are, of course, my own.

I would like to thank Per Cramér, Andreas Fischer-Lescano and Anna Wrange for their comments on an earlier draft. ${ }^{2}$ For Machiavelli speaks not only my current setting in Florence, but a certain familiarity as well as fascination for his writing, a fascination which shares some traits with that for Carl Schmitt (see below).

${ }^{3}$ If mentioned at all in histories of the subject, it is as one of the deniers of international law, along with Hobbes and Hegel. See, e.g., Karl-Heinz Ziegler, Völkerrecbtsgescbicbte (Verlag C.H. Beck: München, 1994) at 164. Zeigler reserves the term 'Völkerrechtsleugner' for Hobbes ( $p$ 194), but he makes clear that for Machiavelli law was of no significance.

${ }^{4}$ Much has been made of the triad site/sight/cite. While they fit nicely together in a text like this, the fact that they happen to be homonymous, and therefore quite usable, is just one example of how thought follows language, rather than the other way around.

${ }^{5}$ Quentin Skinner, Machiavelli (Oxford University Press: Oxford, 1981). NM (1469-1527) was appointed Secretary in the Republic of Florence in 1498, after the execution of Savonarala. He was fired by the returning Medici's upon the demise of the republic in 1512. This meant the start of his somewhat frustrating career as a writer, with the Prince being the first work, finished already in 1513. He divided the remainder of his life between tending to his inherited little estate outside Florence, producing the texts that have made him immortal and sometimes taking on jobs as a free-lance negotiator or adviser. Though remaining a Republican at heart, NM was sometimes - but much too rarely for his own
} 
- that sums up Martti Koskenniemi career (assuming that we add 'in/of international law').

3. In 1998 the Legal adviser of the United Nations invited a number of colleagues to discuss the role of the legal adviser. In the ensuing volume with a great number of contributions from practitioners, there are many insights on the often difficult position of the legal adviser. ${ }^{6}$ There is, however, not a single reference to any work by Machiavelli, arguably the most famous adviser in political history, and often himself in a difficult position.

Machiavelli naturally had a bit to say about the arts of advising and receiving advice: The adviser should know that "whoever has in hand the state of another must never think of himself but of the prince.' The prince, on his part, 'ought to discourage absolutely attempts to advise him unless he asks it, but he ought to be a great asker, and a patient hearer of the truth about those things of which he has inquired' and he should 'comport himself so that every one may see that the more freely he speaks, the more he will be acceptable.' But after the advise, the Pprince must 'deliberate by himself in his own way.' 'Therefore it must be concluded that wise counsels, from

taste - employed by the new rulers, most intensely during the crucial months preceding the catastrophic sack of Rome by the Spaniards in 1527. Having apparently compromised himself during the intervening 15 years, he was not reemployed when the Republic was (briefly) reinstated in 1527, and died disheartened only a few days thereafter. There are many biographies of Machiavelli, and I have studied the very readable one by Maurizio Viroli - who also is intimately familiar with Machiavelli's political writings (see footnote 18) - Niccolo's Smile: A Biography of Machiavelli (Antony Shugaar transl, Farrar, Straus and Giroux: New York, 2000). His life is also treated in, e.g., Anders Ehnmark, Maktens hemligheter: En essä om Machiavelli (Norstedts: Stockholm, 1986) and in Skinner, Machiavelli supra.

I have used the following edition of the two Machiavelli texts cited here: Niccolò Machiavelli, The Chief Works and Others (A. Gilbert, trans, Durham, 1965). Since the books have been published in so many different editions, I have also indicated the Chapter. 'The Prince' is cited 'The Prince' and the 'Discourses on the first ten Books of Titus Livius' are cited 'Discourses'.

${ }^{6}$ Collection of Essays by Legal Advisers of States, Legal Advisers of International Organizations and Practicioners in the Field of International Law (United Nations: New York, 1999). 
whoever they come, must necessarily be due to the prudence of the prince, and not the prudence of the prince to the good counsels received. ${ }^{7}$ This are wise words, but I suppose that any legal adviser would read them not only with a certain degree of recognition but also with somewhat mixed feelings: The prince should listen but in the end it is up to his virtù (see below) to make the right decision. We will reverse this position in the course of this essay.

Machiavelli is often held to be the father of realism. ${ }^{8}$ Now, it is a universal virtue to be realistic, but less so being an adherent of the self-dubbed 'realist' school of international politics, which is based on a limited reading of 'reality', to a large degree (a)(e)ffected by the very men and women who claim to take things as they really are. And NM has even become an icon for cynicism, an 'evil man', to quote Leo Strauss. ${ }^{9}$ It probably seemed far-fetched for the legal advisers to invoke such a tradition.

4. But there is a lot more to Machiavelli than 'realism,' such as is his conception of virtù. Virtù is a necessary trait for a man who wants to do great things, but it will not necessarily lead to success, since virtù is always in interaction or battle with Fortuna ('fortune'). In history, virtù has meant many things. ${ }^{10}$ For NM, it refers to both the abilities and to what we today would call 'virtue'. ${ }^{11}$ The virtuoso has to be not only

\footnotetext{
${ }^{7}$ Niccolo Machiavelli, The Prince, 86-88, Chapters XXII-XXIII.

${ }^{8}$ See, e.g., Steven Forde, 'Classical Realism' in Traditions of International Ethics (T.Nardin \& D.R.Mapel ed., Cambridge University Press: Cambridge, 1992) 62, at 64 et sequal.

${ }^{9}$ Leo Strauss, Thoughts on Machiavelli (1958) at 9.

${ }^{10} \mathrm{It}$ is, in a way, an expression similar to honour, which can have different meanings in different cultures, but which occupies a similar place in various discursive systems.

11 The word 'virtù' (virtus) is sometimes translated with 'ability', sometimes with 'virtue', as in another translation which I have used (Niccolo Machiavelli, The Prince and the Discourses (Luigi Ricch trans, E.R.P. Vincent rev, The Modern Library (Random House): New York, 1950) at 19 (Chapter VI) and at 32 (chapter VIII), respectively): It may be appropriate to translate virtù in this fashion if one thinks that Machiavelli used the same word for different concepts, that is, if he meant different things in Chapter VI and Chapter VIII of 'The Prince'. Skinner argues, however, quite
} 
virtuous (good) but also able. And she has a mission, a telos, to act for the common good, as we will see. ${ }^{12}$

Machiavelli's preoccupation with virtù was typical of his days. The Prince was one in a long series of Fürstenspiegeln, ${ }^{13}$ which point at the important role played by the personal characteristics of the leader. Later, theory learned to dispose of the individual, and became a whole in itself, as in Hobbes Leviathan. ${ }^{14}$

5. For us, post-moderns (post-modernists or not), who no longer believe in the logical truth or closure of the legal system or any other system of thought, it all (again) appears to boil down to the personal characteristics of those who participate in the production of international law. This was also an implication of the moving last 12 pages of Martti's From Apology to Utopia $(A / U)$. After almost 500 pages of trashing of international legal discourse, Martti pointed not only at the possibilities of a new discourse, but perhaps most of all at the personal responsibility of the international lawyer. ${ }^{15}$

convincingly that the term should remain untranslated (Skinner, supra note 5 , at 8 ). I believe that virtù, which is a central concept for Machiavelli, is one concept, which covers both 'virtue' (though not with the conventional denotation or reference) and 'ability'. For that reason, I do not believe that Machiavelli was a realist in the contemporary, 'scientific' meaning, since he did not fully severe politics from moral, and even less the empirical from the normative.

Nevertheless, the important thing for me - not being a historian of ideas - is not whether this is correct, but whether 'virtù' is an interesting concept, and I believe that it is.

12 Niccolò Machiavelli, Discourses, supra note 5, at 218.

13 Books written for princes - the leadership and management literature of the day, but often more moralising and idealising.

14 see John Watkins, Hobbes's system of ideas (2 ed, 1973) at 19-21. Nonetheless, Hobbes had some interesting things to say about 'Councsell' (sic). Thomas Hobbes, Leviathan (first published 1651) (Q. Skinner ed, 1991) at 176-182.

15 Martti Koskenniemi, From Apology to Utopia: The Structure of International Legal Argument (Lakimiesliiton Kustannus: Helsinki, 1989) [hereinafter A/U] at 476-501 and in particular 490-501. I have critiqued A/U sympathetically in Pål 
Martti's second grand oeuvre, The Gentle Civilizer of Nations, tells the same story as $A / U$, but from a different perspective. We do not tear down the famous canonical texts of international law, but meet their authors. Like their texts, they fail. Nevertheless, as persons many of them are inspiring, sometimes heroically, often tragically. It is not the victors of History we meet, but the losers: our intellectual grandfathers in a discipline, which has often felt quite marginalised. ${ }^{16}$

6. Machiavelli's two most important works are the Prince and the Discourses on Livi. ${ }^{17}$ One is, if you will, a revelation of the wicked nature of royal politics, the other a historical review of republican politics and its possibilities. Machiavelli spends a considerable number of pages of both the Prince and in particular of the Discourses on the question of how to proceed from liberation and retain the liberated status. It is necessary to liberate to have freedom. But the virtù necessary for the liberation is not necessarily that needed for liberty.

Is there a difference between liberation from a vicious Prince and liberation from a constraining discourse, like international law? After all, legal rules are part of régimes, the same word as is used for a ruling government. A political arrangement always include discursive arrangements, and discourses always have institutional underpinnings. Machiavelli spent much of his time tearing down an old discursive (Christian) orthodoxy, which was a universalism. This was a scandal. At the same time, he participated, in the construction of a new paradigm, which was to become

\footnotetext{
Wrange, 'Från domstolssession till jamsession eller Martti Koskenniemi och juridikens slut' [From court session to jam session or Martti Koskenniemi and the end of law], Retfard No 64 (1994) 3-22.

${ }^{16}$ Martti Koskenniemi, The Gentle Civilizer of Nations: The Rise and Fall of International Law 1870-1960 (Cambridge University Press: Cambridge, 2002) [hereinafter The Gentle Civilizer of Nations].

17 See footnote 5 .
} 
an orthodoxy - the conception of the state and the raison d'état. ${ }^{18}$

A common way to liberate is by introducing a new (putative) orthodoxy. But often, the liberators are united by nothing but the discontent with the existing. The liberation suggested by critical legal scholars, such as Martti, offers no new dogma's, no régime for the liberated law, only a way to liberate. ${ }^{19}$

7. It is July, 2002. Walking between addresses on first and second avenue in Midtown, New York, I perform many tasks on the same day, switching routinely between them. In the morning in my room, reading the documents for the last meeting of the Preparatory Commission (PrepCom) for the International Criminal Court (ICC), I am the analyst. Later, during the meetings in various conference rooms in the UN building, I alternate between being an advocate for a 'national position' (not infrequently a stance which I have decided myself in the course of a few hours or minutes) and being a manager, someone who tries to help the process, by giving in or suggesting solutions to cater for special needs of different other countries. Later in the day, at the Swedish mission to the UN, I turn into an adviser for my government and for our permanent representative to this organisation. (A different, but very

\footnotetext{
18 See, i.a., Jens Bartelson, A Genealogy of Sovereignty (Cambridge University Press: Cambridge, 1995) at 111-121, Maurizia Viroli, Machiavelli (Oxford University Press: Oxford, 1998) at 42 et sequal and footnotes at 191-192. Schmitt dealt with Machiavelli's role in Der Dikatatur (John P. McCormick, Carl Schmitt's Critique of Liberalism: Against Politics as Technology (Cambridge University Press: Cambridge, 1997) at 131). The term 'reason of state' seems to have been coined by NM's good friend Francesco Guicciardini in his 'Dialogue of the Government of Florence' (Viroli, Machiavelli, supra, at 50).

${ }^{19}$ For sure, Martti has a lot to say about what attitude we should take in approaching our problems. But there is no methodology, no regime of truths in Michel Foucault's sense (see Michel Foucault, The Archaeology of Knowledge, (Tavistock: London, 1972)). On this problem, see also numerous works by David Kennedy, in particular the rich, wonderful 'When Renewal Repeats: Thinking Against the Box', 32 New York. University Journal of International Law and Politics (2000) 335-500. I disagree, though, at least on its face, with the assertion that the distinction between critics and reformers is not very useful ( $\mathrm{p}$ 463). It is true that '[e]veryone is doing both', but not to the same degree or in the same way.
} 
related issue has turned up. The US is trying to protect its peace-makers from the jurisdiction of the Court through a proposed action in the Security Council which, they claim, is in conformity with Article 16 of the Court's Statute; see footnote 42 and surrounding text).

All through the day, I change perspective, though in the very same professional role, a delegate to the ICC PrepCom. But in my wider identity as an international lawyer, I also have other affiliations, as Martti so nicely describes it in $A / U$, as well as in his own contribution to the volume of articles by legal practitioners. ${ }^{20} \mathrm{I}$ am not only the national bureaucrat, but also the Grotian cosmopolite ${ }^{21}$ - an activist in a bureacratic dress (and a participant in 'the new diplomacy'22), acting from the perspective of the common good. Many different views have to be reconciled -the global perspectives, the UN perspectives, the EU perspectives and the national perspectives, the latter always being the final arbiter (but none of them ever being uniform, stable or given).

While switching between these roles and perspectives, I like to think that my actions revolve around an identity. That identity is, of course, but a product of my present and past sights/sites/cites, and of my own conscious efforts of self-creation, professional and private. Just as I am now much more comfortable buying suits than buying jeans, I am much more comfortable reading and writing speaking notes, than writing an essay like this one. But one never forgets completely. When I go downtown to a new joint on the Lower East Side, I recall my old, slightly more bohemian self. When I write this piece, it is as if nothing had changed since I was an

\footnotetext{
${ }^{20}$ Martti Koskenniemi, 'Between Commitment and Cynicism: Outline for a Theory of International Law as Practice', Collection of Essays by Legal Advisers of States, Legal Advisers of International Organizations and Practicioners in the Field of International Law (United Nations: New York, 1999) 495-523.

21 Martti Koskenniemi, A/U supra note 15, at 476-501 and in particular at 493-494.

22 This is an expression, which denotes modern diplomacy in which NGO's play a prominent role.
} 
academic six years ago. And yet it has. One competence, one perspective has been added to another, and in the meantime, the way I use the old competence has changed. In my best moments, I sense that I can transfer experiences from one site to another (at other times, I feel too immersed in whatever occupies me in that instant).

8. Carl Schmitt was another adviser/academic, busy switching positions and remaking himself, while still retaining a certain sense of unity in thought. ${ }^{23}$ After a brief and despicable career as Kronjurist in the early years of the Third Reich, Schmitt was under investigation in Nuremberg for alleged complicity in the Nazi crimes. He denied any legal responsibility, claiming that his role had been only that of an academic - as if only the Prince were responsible, never he who produced the Discourse. He did admit, though, that a writer has responsibility in a wider sense for his/her words. ${ }^{24}$ The rest of

\footnotetext{
${ }^{23}$ Despite a large production spanning over most of the $20^{\text {th }}$ century, Schmitt never published a comprehensive tract of his ideas, and much of what he wrote was spurned by political events of the day. For an effort to make an intertextual reconstruction of his work, see Gopal Balakrishnan, The Enemy: An Intellectual Portrait of Carl Schmitt, (Verso: London and New York, 2000) [hereinafter The Enemy].

${ }^{24}$ On Schmitt's cooperation with the Nazis, see generally i.a. Joseph W. Bendersky, Carl Schmitt: Theorist for the Reich, (Princeton University Press: Princeton, 1983) at 195 et sequal and also Reinhard Mehring, Carl Schmitt zur Einführung, (Junius: Hamburg, 1992) at 101-124. See Bendersky, supra at 227-229 and 235 et sequal as well as Heinrich Meier, The Lesson of Carl Schmitt: Four Chapters on the Distinction between Political Theology and Political Philosophy (Marcus Brainard transl, The University of Chicago Press: Chicago and London, 1998) at 151 et sequal on Schmitt's anti-Semitism and antiSemitic activities. See Bendersky, supra at 256-261 and 270 and William E. Scheuermen, Carl Schmitt: The End of Law (Rowman \& Littlefield Publishers: Lanham, etc, 1999) at 157-170 on the relation between his Großraum theory and Nazi expansionism.
}

Schmitt was interned and interrogated, i.a. in Wannsee and Nürnberg, during two periods in the years 19451947. His responses in Nürnberg have been published in Carl Schmitt, Antworten in Nürnberg (published and commented by Helmut Quaritsch, Duncker und Humblot: Berlin, 2000) [cited Antworten in Nürnberg], and referred i.a. i Bendersky, supra, at 271-272. In one of the interrogations, Schmitt said i.a. the following: 'I am an intellectual adventurer. ... [T] houghts and ideas emerge. I take the risk. I have always paid my bills, and have never played the shirker.' (Antworten in Nürnberg, at 60; translation taken from Gopal Balakrishnan, The Enemy, supra note 23 at 255. Besides the oral interrogations, he also submitted a number of written positions (Stellungnahme). In the first one, he claimed that he had only thread the path of science (Wissenschaft), indifferent as to whether the 'loudspeakers' of daily politics approve or not. The scientific researcher must expect that his impulses of thought and the methodological 
his life till his death in 1985 he spent in relative seclusion in his hometown Plettenberg, often comparing himself with Machiavelli in his refuge in San'Andrea in Percussina (San Casciana)..$^{25}$

In spite of his quite dubious politics and moral, Schmitt was one of the century's most interesting thinkers in legal and political theory, as Martti makes quite clear in The Gentle Civilizer. ${ }^{26}$ One of Schmitt's most important concepts, a rather late one, is the Nomos: Nomos is the shape ('Gestalt') of the political, social and religious order ('Ordnung'). It is the full immediacy ('Unmittelbarkeit') of a legal force which is not mediated through law (statute; 'Gesetz'); it is a constituting, historical instance ('Ereignis'), an act of legitimacy, which makes sense of the legality of the law. ${ }^{27}$ Hence, Nomos is beyond but not unrelated to the law. While not being a source in the formal sense, it is in some respect a determinant and source of meaning of the law.

pursuit of his argumentation protect him and his scientific intentions from being equalised with political propaganda (Antworten in Nürnberg, at 68). In the second one he developed on that theme: The results of research are meant to provide an approach (Ansatz) for further thought and scientific discussions. Still, the formulations may be used for political purposes (Antworten in Nürnberg, at 88). But, interestingly, he also drew a distinct line between legal responsibility and responsibility in a wider sense (Antworten in Nürnberg, at 89). While his activities did not make him legally responsible for his writings (and the prosecutorial authorities agreed, PW), each author has a great responsibility and is accountable for his or her words (Antworten in Nürnberg, at 89-90).

25 On Machiavelli's life, see footnote 5. On Schmitt's life after the war, see Bendersky, supra note 24, at 274 et sequal, in particular p 287 on his comparing himself with Machiavelli.

${ }^{26}$ Martti has dealt with Schmitt in both A/U (Martti Koskenniemi A/U supra note 15, at 194-200) and more extensively in The Gentle Civilizer of Nations (Martti Koskenniemi, The Gentle Civilizer of Nations, supra note 16, passim in chapter 6, at 413-510). I have used Schmitt i.a. in Pål Wrange, 'Downtown, Midtown, Uptown, Review of Louis Henkin, 'International Law: Politics and Values' and Thomas M. Franck, "Fairness in International Law and Institutions"', 68 Nordic Journal of International Law (1999) 53-83.

${ }^{27}$ Carl Schmitt, Der Nomos der Erde im Völkerrecht des Jus Publicum Europaeum (Duncker \& Humblot: Berlin, 1950) at 40 and 42 . 
9. What sort of virtù is demanded of the international lawyer? The lawyer is trained to answer the question 'what is valid law' (a task which Martti defends ${ }^{28}$ ). But, as Martti also explains, nothing prevents the lawyer from also going beyond that, and transgress her disciplinary borders ${ }^{29}$ (as long as the value of the borders is respected), just like her interlocutors among diplomats and statesmen have transgressed theirs.

The saying that international law is 'dynamic' can be used to justify anything. But, it is a relevant truism that international law is not only a system of valid law (which has to be frozen every time the question 'what is valid law' is to be answered). It is also a developing system, and the lawyers as actors take part in that development. There are no independent observers, at least not in the legal profession.

Here is a soundbite which often comes to mind (as told by a colleague who was present): After having finished his pleadings before the International Court of Justice in the Nicaragua Case in 1986, Ian Brownlie, council for Nicaragua, closed his books, looked at the court and said something like this: When you make your decision, think about what it is you are condoning. ${ }^{30}$

10. What sort of order comes out of the ICC controversy, or of Afghanistan and Iraq? In the 1990's the defining word was 'democracy', coupled with human rights and market economy. The ad hoc tribunals for former Yugoslavia and Rwanda, the ICC, Kosovo and, at a more pedestrian level, various human rights and economic policy conditions for

\footnotetext{
${ }^{28}$ Martti Koskenniemi, The Gentle Civilizer of Nations, supra note 16, at 495.

${ }^{29}$ Cf Martti Koskenniemi, A/U supra note 15, at 476-501.

${ }^{30} \mathrm{I}$ have not found those or similar words in the records. However, the last paragraphs of Professor Brownlie's pleading very forcefully make that point. Military and Paramilitary Activities in and against Nicaragua (Nicaragua v. United States of America) ICJ Pleadings, vol V (1986) at 234-235. As is well-known, the Court found, to Professor Brownlie's liking, that the US was guilty of unlawful use of force, etc, vis-à-vis Nicaragua.
} 
development co-operation, credits, trade, etc - they all signalled that the new world was one where the relationships were to be defined by the state's attitude to democracy, the rights of the individual and economic freedom. The driving forces were advocacy NGO's and international business, and the engineers were the international civil service and liberal governments. ${ }^{31}$ The defining (or crowning) moment was March 24, 1999 the Pinochet judgement of the House of Lords and the beginning of what many of us called a humanitarian intervention in Yugoslavia.

September $11^{\text {th }} 2001$ symbolised a change. The beginning of the military campaign against Afghanistan on October $7^{\text {th }}$ was not necessarily a harbinger of a new order - a US government could not have acted very differently. ${ }^{32}$ And while terrorism does threaten democracy, human rights and market economy, it cannot in itself - on its present scale -bring such changes. However, what could be taken to define a new order were a few surrounding sets of events. Firstly, the new US administration quickly enrolled as allies a number of dubious regimes which had been kept at arms length by the liberal governments of the 90's (the US, the EU and others). Hence, it seemed, what determines which side you are on is primarily your relation to terrorism. ${ }^{33}$ The second event was, of course, the doctrine of pre-emptive self-defence, developed by Pentagon

\footnotetext{
31 This was a movement also in international law. The arguably most consistent expression of this view is Anne-Marie Slaughter, 'International Law in a World of Liberal States', 6 European Journal of International Law (1995) 503-538. For a very astute critique, see Susan Marks, The Riddle of All Constitutions: International Law, Democracy, and the Critique of Ideology (Oxford University Press: 'Between Commitment and Cynicism: Outline for a Theory of International Law as Practice', Oxford, 2000). Though I have great sympathy for the liberal doctrine in practice, I also have some severe principled and theoretical difficulties, which I have expressed, i.a., in 'Liberalism and the end of international law?' Paper presented at the International Studies Association Conference, Los Angeles 18 March 2000.

32 In my not very unusual view the US had a right of self-defence.

33 That is not unqualified, though, because according to neo-conservative foreign policy thinking, quite prevalent in the US Administration, there are immutable principles of universal justice (Andrew Hurrell, "'There are no Rules" (George W. Bush): International Order after September 11', 16 International Relations (2002) 181, at 185). Cf also several such references in the West Point speech (see footnote 34, below).
} 
and presented by President Bush at his speech to the graduates at West-Point in June, $2002,{ }^{34}$ applied as a threat against Iraq, ${ }^{35}$ and in effect endorsed by the US Congress. ${ }^{36}$

The US campaign against the ICC ${ }^{37}$ is not of the same magnitude as its struggle against al-Qaida and Saddam Hussein (it is both smaller and broader in scope). But together they have a symbolic significance, which some would read: The most powerful nation in history from now on measures every relationship mainly by one yardstick - threats to the United States - and is further prepared to use all the means at its disposal to go after its enemies, but does not wish to be held accountable. Or, in more Schmittean terms: 'The Empire $^{38}$ has in expressis verbis asserted the right to decide on the exception, ${ }^{3940}$ on its

\footnotetext{
34 'Remarks by the President at 2002 Graduation Exercise of the United States Military Academy', 1 June, 2002, <http://www.whitehouse.gov/news/releases/2002/06/20020601-3.html>. See also the National Security Strategy, at $<$ http://www.whitehouse.gov/nsc/nss.html $>$.

35 At the time of writing, no big scale military force has been applied against Iraq by the present administration. The routine bombings in the no-fly zone are justified by the US on partly different premises and are not necessarily indicative of any change in US or world politics.

36 'Joint Resolution to Authorize the Use of United States Armed Forces Against Iraq'

<http://www.whitehouse.gov/news/releases/2002/10/print/20021002-2.html>

${ }^{37}$ Apart from the article 16 controversy, the US has also tried to reach agreement with other nations that they will never surrender a US national to the ICC. These agreements are, in the US view, based on article 98 of the Rome Statute. I disagree, but it would lead to far to explain why. The EU has adopted a stance which is well-based on the Statute. See <www.iccnow.org $>$.

${ }^{38}$ This term is a citation from current political discourse. It is widely taken to denote the US, but I do not claim that it is appropriate. A quick search at the 'www.google.com' gave more than 78.100 returns for 'empire' and 'United States'. A sample indicated that roughly $25 \%$ concerned suggestions that the US is an Empire. Martti Koskenniemi also uses the denomination (Martti Koskenniemi, The Gentle Civilizer of Nations, supra note 16, at 480). The term has been most famously used in Michael Hardt \& Antonio Negro, Empire (Harvard University Press: Cambridge, Mass, 2000), in a quite peculiar meaning. For a discussion focusing on Hardt's and Negro's work, see Tarak Barkawi \& Mark Laffey, 'Retrieving the Imperial: Empire and International Relations', 31 Millenium (2002) 109-127.

39 This is, of course, an allusion - but no more - to Carl Schmitt's formula 'Sovereign is he who decides on the exception.' See Carl Schmitt, Political Theology (first published 1934) (2 ed, translated by George Schwab, MIT Press, Cambridge, Mass, 1985) at 5. Political theology is, by the way, not a completely unjustified term in this context.

${ }^{40}$ Richard Perle, head of the Defense Policy Board in Pentagon and one of the leading policy-makers in the Bush administration, claims that a preemptive attack against Iraq would be in agreement with international law. Further: ‘ $[$ f I have to choose between some abstract concept of the international community and protecting the citizens of this country, there's no question what comes first.' ('Striking first', A Jim Lehrer NewsHour, 1 July, 2002,
} 
view of universal 'moral truth'. ${ }^{41}$

11. The negotiations in the Security Council drag on. As it turns out, a resolution will be passed on July 12, my very last night in New York, before going to Florence to look for an apartment.

One afternoon towards the end of this process, there is a meeting (one of many) of the heads of delegation of the EU member states. A new compromise draft, clearly acceptable for the US is being presented. According to one ambassador, it is a great improvement, another calls for a bottom line. A colleague, a good lawyer and a friend of the court, defends the text. In my reading there is no significant difference between this draft and the last and deeply problematic one, presented a few days ago. One ambassador introduces an amendment. In legal terms, the added words are ambiguous, he explains, making them juridically ludicrous but politically helpful.

What should we make of this document? It all turns on whether Article 16 of the Rome Statute of the ICC is to be read in isolation or against the context of the will of (the majority of) the parties, the purpose of the treaty, or in some other of the several methods provided for in articles 31 and 32 of the Vienna Convention of the law of

<http://www.tni.org/archives/bennis/newshour.htm>).

At any rate, to assert such power might not necessarily be easy. See, i.a. Steve Smith, 'The End of the Unipolar Moment? September 11 and the Future of World Order', 16 International Relations (2002) 171, at 177-178.

41 This is a citation from the West-Point speech: 'Moral truth is the same in every culture, in every time, and in every place. Targeting innocent civilians for murder is always and everywhere wrong. (Applause.) Brutality against women is always and everywhere wrong. (Applause.) There can be no neutrality between justice and cruelty, between the innocent and the guilty. We are in a conflict between good and evil, and America will call evil by its name. (Applause.) By confronting evil and lawless regimes, we do not create a problem, we reveal a problem. And we will lead the world in opposing it. (Applause.)' See supra note 34. 
treaties. ${ }^{42}$

12. Any account of international law, which assumes that international law and world order are the same is flawed. But any account of international law, which does not take world order into account is incomplete. As an adviser, I must state what it is we are or are not condoning. The political repercussions will be explained by colleagues - from the Department of the Americas, the Department of Global Security, the Ministry of Defence, and so on - but I (and other international lawyers) will contribute to explaining what they mean to world order. And I seldom find it difficult to bring across the difference between welcoming or not welcoming a Security Council resolution exempting forces from the jurisdiction of the ICC or the implications of a military campaign in real or perceived self-defence against the one or the other country. It is a

42 Article 16 of the Rome Statute of the International Criminal Court provides:

'No investigation or prosecution may be commenced or proceeded with under this Statute for a period of 12 months after the Security Council, in a resolution adopted under Chapter VII of the Charter of the United Nations, has requested the Court to that effect; that request may be renewed by the Council under the same conditions.'

In its Resolution 1422 of July 12, 2002, the UN Security Council,

'Acting under Chapter VII of the United Nations Charter,

1. Requests, consistent with the provisions of Article 16 of the Rome Statute, that the ICC, if a case arises involving current or former officials or personnel from a contributing State not a Party to the Rome Statute over acts or commissions relating to a United Nations established or authorized operation, shall for a twelvemonth period starting 1 July 2002 not commence or proceed with investigation or prosecution of any such case, unless the Security Council decides otherwise;

2. Expresses the intention to renew the request in paragraph 1 under the same conditions each 1 July for further 12-month periods for as long as may be necessary;

3. Decides that Member States shall take no action inconsistent with paragraph 1 and with their international obligations;

4 Decides to remain seized of the matter.'

Earlier drafts had, i.a., provided for an automatic renewal in paragraph 2 as well as total immunity - even in domestic courts, and even for crimes against which states had undertaken in the Geneva Conventions and their Additional Protocols, the Convention against Torture or the Genocide Convention to prosecute or extradite! The remaining controversy in the final text concerned, i.a., whether article 16 could be invoked generically in this way or only in a particular case or a particular situation. Further, there were doubts as to whether this really constituted a situation where Chapter VII of the UN Charter was applicable. 
technical question of the application of articles 31 and 32 of the Vienna Convention of the Law of Treaties to another treaty (be it the UN Charter or the Rome Statute), but it is never only that. It is also a matter of Ordnung, or Nomos.

13. The whole issue of Article 16, one of the most divisive in New York for years, was so legal. Legal texts were being discussed, international law was revered, and international lawyers were involved., Still, beneath that surface, law seemed less revered than used, even abused. After all, this, we felt, was not a fight within international law, but against it.

Looking back, my own analyses, sceptical of the successive Security Council drafts, seem biased. ${ }^{43}$ But that is a derogatory judgement, only if you look at it from a narrow, technical perspective. The truly decisive question for us was not, I believe, whether the Rome Statute, or the UN Charter for that matter, allowed the decision by the Council, because we admit that international law is an open-ended discursive system where there is always room for another argument ( although not all arguments are equally acceptable). Instead, the decisive question was what sort of Nomos it was promoting. We worked with the intention to establish a new order through, or built on, law, ${ }^{44}$ in defiance of the premises determined by Schmitt. ${ }^{45}$ Our advice had been to the point, legally and politically, and it had been listened to and taken into account. But the forces were not on our side. Or maybe there was something wrong with our

\footnotetext{
${ }^{43}$ Which does not mean that they were unjustified, given the premises of international law and order, which I and my colleagues proceed from.

${ }^{44}$ Of course, no one thought that that would be easy. There is, after all, a deep tension between the 'constitutional' order of international law and the structures of power politics (see Hurrell, supra note 33, at 202).

${ }^{45}$ Machiavelli held that the laws had an important role in preserving virtù (Discourses, 201). That, of course, applies in a Republic and not in international relations (a concept not invented in Machiavelli's days).
} 
premises.

14. Machiavelli's discursive development went from 'how it is' (the despatches sent to Florence from various courts and war camps in Central Italy and other places) to 'how it is' (The Prince) to 'how it should be' (The Prince, but most of all the Discourses). ${ }^{46} \mathrm{NM}$ united the pessimism of intelligence with the optimism of the will. ${ }^{47} \mathrm{He}$ united the understanding of the problems of the recurring (the cynicist) with those of change (the optimist). ${ }^{48}$ An order had to be established, by a virtuous man, for the purpose of driving out the barbarians and liberating Italy. ${ }^{49} \mathrm{He}$ failed, but in the process he developed a discourse, which participated in shaping our thinking about things international.

15. What are we, international lawyers? Are we the gentle civilizers of international politics? Or the builders of a Potemkin village, behind which politics goes on as usual? Or perhaps the new rulers of the world?

In a recent article, Peter J. Shapiro finds that globalisation brings tremendous opportunities for international lawyers, if only we are able to seize them. 'Indeed international law is now positioned to be a first-mover in both the law and the social sciences', even to acquire 'dominance'. ${ }^{50}$ This sounds reassuring for someone who is used to defending his profession, or to hearing that international law should turn to

${ }^{46}$ Cf Anders Ehnmark, Maktens hemligheter: En essä om Machiavelli (Norstedts: Stockholm, 1986) at 68.

47 Ehnmark, supra note 46, at 109. In Schmitt's reading, though, Machiavelli is but a technician. See John P.

McCormick, Carl Schmitt's Critique of Liberalism: Against Politics as Technology (Cambridge University Press: Cambridge,

1997) at 130 .

48 Ehnmark, supra note 46, at 206.

${ }^{49}$ Niccolo Machiavelli, The Prince, supra note 5, at 94 et sequal, Chapter XXVI.

50 Peter J.Shapiro, 'Globalization, International Law, and the Academy', 32 New York University Journal of International Law 
neighbouring disciplines, such as EU law or international relations, for inspiration, to make the field more 'constitutional' or more 'relevant'. But, the international law thus liberated would be a discipline no longer recogniseable - having taken full account of globalisation and the non-state actors. Perhaps that is the way to go (I do not want to be ironic about it), or perhaps we should settle for liberation without domination, or even defer liberty and just look for the specificity of our discipline in the site being allocated to it. At any rate, what it is that we (myself and most colleagues that I know) are after is not more international law per se, but more justice. Not more job opportunities, but a better world. Not more realism but more real goods. ${ }^{51}$ So we could do worse than take part in David Kennedy's project 'to figure out how the discipline participates in keeping a terribly unjust international order up and running ${ }^{52}$ (while rejoicing in the fact that we have probably also participated in preventing some injustice).

16. Few people have thought more acutely about these issues than Martti. In The Gentle Civilizer of Nations, he recycles concepts critisised in his earlier works - formalism and universalism - but fills them with a new, positive content, to avoid the imperialism of the 'culture of dynamism': The culture of formalism resists being reduced to either structure (i.e., the undeterminate structure of international law) or the plain decision by the powers that be. While rejecting the claim that there are universal truths, this formalism 'projects the universal community as a standard - but always as an

and Politics (2000) 567 at 587 and 590.

51 This is, by the way, how I read Philip Alston, 'The Myopia of the Handmaidens: International Lawyers and Globalization', 8 European Journal of International Law (1997) 435-448. See also David Kennedy, ‘A New World Order: Yesterday, Today, and Tomorrow', 4 Transnational Law and Contemporary Problems (1994) 1.

52 David Kennedy, 'When Renewal Repeats: Thinking Against the Box', 32 New York University Journal of International Law and Politics (2000) 335, at 456. 
unachieved one'. ${ }^{53}$

These words are easy to read and to appreciate. But they require hard thinking and difficult choices to apply. Be it as diplomats, advisers, philosophers or historians, we have to concern ourselves with the implications of what we do or say. As two contemporary scholars in international relations write, 'even the most powerful need to legitimize their power' and 'the future world order depends on the choices our leaders make'. ${ }^{54}$ Those choices are influenced by the advice they receive and the intellectual climate in which that advice is conceived and given. ${ }^{55}$

The most important thing to teach a young aspiring international lawyer (and any other person in a responsible position, that is, everyone), is to constantly reflect on his or her professional position, and remind her to always rely on and construct her virtù. This is not only a personal business. It has to be carried out as deliberative moral and reflexive knowledge, where the Ego constantly not only questions herself but also lets herself be questioned by others and exposed to ideas, views and experiences other than her own. So, the perception of the precise implications of the responsibility must and will change, but one thing has to remain: the understanding that the responsibility is there. And at all times, she must be both sceptical and optimistic at the same time: To see the world as it is, but to also read it through a

\footnotetext{
${ }^{53}$ Martti Koskenniemi, The Gentle Civilizer of Nations, supra note 16, at 508 and at 494-517. Nomos is dealt with at 415422.

54 Andrew Hurrell, supra note 33, at 189 and Steve Smith, supra note40, at 182.

55 Some may take this to be a call to limit academic freedom. I do not think so. I believe that the distinction set out by Schmitt in Nürnberg is relevant, in spite of the particular circumstances in his case. Academiae should not restrict the freedom of research or debate, and neither should academics abstain from telling the truth (as defined in each case). But every one is morally responsible for the choices which he or she makes within those parameters.
} 
telos. 56

17. In an act no less opportunistic than Carl Schmitt's courtship with the Nazis, but much less spiteful, Machiavelly dedicated 'The Prince' in 1513 to the 'Magnificent' Lorenzo de Medici, the heir in the ruling family of Florence. ${ }^{57}$ This was to no avail, since Lorenzo showed litte interest. In the Discourses a few years later, Machiavelli had changed his mind, and dedicated this new work not to a Prince but to his intellectual friends Zanobi Buondelmonte and Cosimo Rucellai:

'I may seem to have departed from the ordinary usage of writers, who generally dedicate their works to some prince; and, blinded by ambition or avarice, praise him for all the virtuous qualities he has not, instead of censuring him for his real vices, whilst I, to avoid this fault, do not address myself to such as are princes, but to those who by their infinite good qualities are worthy to be such; not to those who could load me with honors, rank, and wealth, but rather to those who have the desire to do so, but have not the power. For to judge rightly, men should esteem rather those who are, and not those who can be generous; and those who would know how to govern states, rather than those who have the right to govern, but lack the knowledge. 58

\footnotetext{
${ }^{56} \mathrm{My}$ own views about the position of the legal adviser have been spelt out briefly towards the end of the article 'Downtown, Midtown, Uptown, Review of Louis Henkin, 'International Law: Politics and Values' and Thomas M. Franck, 'Fairness in International Law and Institutions', 68 Nordic Journal of International Law (1999) 53-83. For the moment, I can do no better than that in response to Martti's challenge to us in 'Between Commitment and Cynicism: Outline for a Theory of International Law as Practice', supra note 20.

${ }^{57}$ This was not the well-known Lorenzo the Magnificent, who died in 1492, but his grandson, who did nothing to deserve the name. This Lorenzo was the heir of the family in 1513, when they had just returned to Florence to subdue the free republic and fire Machiavelli from his post as secretary.

${ }^{58}$ Machiavelli, Discourses, supra note 5, at 102.
} 
Is this what we have to settle for?: To talk to those with virtù, rather than to those with power; to participate in the Discourse hoping that Fortuna will some day make a Prince listen. ${ }^{59}$ 